\title{
FABP3 wt Allele
}

National Cancer Institute

\section{Source}

National Cancer Institute. FABP3 wt Allele. NCI Thesaurus. Code C51242.

Human FABP3 wild-type allele is located within 1p33-p32 and is approximately $8 \mathrm{~kb}$ in length. This allele, which encodes fatty acid-binding protein, heart, plays a role in the growth arrest of mammary epithelial cell and mammary gland differentiation. 